\title{
EFFECTS OF SINGLE AND DOUBLE INFECTIONS WITH Potato virus $X$ AND Tobacco mosaic virus ON DISEASE DEVELOPMENT, PLANT GROWTH, AND VIRUS ACCUMULATION IN TOMATO
}

\author{
OLUSEGUN S. BALOGUN, LEIXIN XU, TOHRU TERAOKA \& DAIJIRO HOSOKAWA
}

Laboratory of plant pathology, Faculty of Agriculture, Tokyo University of Agriculture and Technology, Fuchu-shi, Tokyo 183-8509, Japan, e-mail: osbalo@cc.tuat.ac.jp

(Accepted for publication 21/09/2000)

Corresponding author: O. S. Balogun

BALOGUN, O.S., XU, L., TERAOKA, T., \& HOSOKAWA, D. Effects of single and double infections with Potato virus $X$ and Tobacco mosaic virus on disease development, plant growth and virus accumulation in tomato. Fitopatologia Brasileira 27:241-248. 2002.

\begin{abstract}
The tomato cv. Fukuju $\mathrm{n}^{\circ} .2$ was used for studying the effect of single and double infections with Potato virus $X(\mathrm{PVX})$ and Tobacco mosaic virus (TMV). Mixed infection resulted in a synergistic increase of disease severity, where more growth reduction was seen with simultaneous inoculations than with sequential inoculations at four-day intervals. At five and 12 days postinoculation, the increased severity of the disease coincided with enhancement of virus accumulation in the rapidly expanding upper leaves. The PVX concentration in leaves $\mathrm{n}^{\circ} 5$ to 7 of doubly infected plants was three to six fold that of singly infected ones, as determined by DAS-ELISA. Mixed infection with the $\mathrm{L}$ strain led to higher enhancement of PVX than with the TMV- $\mathrm{L}_{11} \mathrm{~A}$ strain. The concentration of TMV-L was lower in double infection and

significantly higher than TMV- $\mathrm{L}_{11} \mathrm{~A}$ in both singly and doubly infected plants. Analyses of the PVX ORF2 by Western blot and Northern hybridization revealed the pattern of accumulation of the $25 \mathrm{kDa}$ protein and the RNAs, respectively, following those of the virion and coat protein. The strain TMV- $\mathrm{L}_{11} \mathrm{~A}$ overcame the resistance gene in cv. GCR 237 (Tm-1). In the upper leaf $n^{\circ} .8$, the concentration of PVX was three times higher in plants with mixed infection than with $\mathrm{L}_{11} \mathrm{~A}$. The concentrations of the $\mathrm{L}$ and $\mathrm{OM}$ (TMV strains) in both singly and doubly infected plants were at very low levels, and the synergistic effect on PVX concentration and disease severity was not observed.

Additonal keywords: synergism, Western blot, Northern hybridization, DAS-ELISA, virus enhancement.

\section{RESUMO}

Efeito de infecções simples e dupla com Potato virus $X$ e Tobacco mosaic virus sobre o desenvolvimento da doença, crescimento da planta e acumulação de vírus em tomate

A cultivar de tomate (Lycopersicon esculentum) Fukuju ${ }^{\circ}$ 2 foi usada para estudar o efeito de infecçöes simples e duplas com o vírus $\mathrm{X}$ da batata (Potato virus $X, \mathrm{PVX}$ ) e o vírus do mosaico do fumo (Tobacco mosaic virus, TMV). A infecção mista resultou em um aumento sinérgico da severidade da doença, mostrando maior redução no crescimento com inoculação simultânea do que com seqüencial. Entre cinco e 12 dias após a inoculação, o aumento da severidade da doença coincidiu com o incremento no acúmulo de vírus nas folhas jovens. A concentração de PVX nas folhas $n^{\circ} 5$ e 7 de plantas com infecção mista foi três a seis vezes mais que a observada com apenasPVX, conforme determinado por DASELISA. A infecção mista com a estirpe L resultou em maior

incremento de PVX do que com $\mathrm{L}_{11} \mathrm{~A}$. A concentração do TMV$\mathrm{L}$ foi mais baixa em infecção dupla e significativamente mais alta do que a de TMV-11A, tanto em infecção simples como em dupla. Análises da OR F2 de PVX por Western Blot e Northern hybridization revelaram o padrão de acúmulo da proteína $25 \mathrm{kDa}$ e RNAs, respectivamente, seguindo aqueles dos viriões e capa proteica. A estirpe TMV-L $\mathrm{L}_{11} \mathrm{~A}$ venceu a resistência genética na cV GCR 237 (Tm-1). Na folha superior $n^{\circ} 8$, a concentração de PVX foi três vezes maior nas plantas com infecção mista com TMV$\mathrm{L}_{11} \mathrm{~A}$. As concentrações das estirpes $\mathrm{L}$ e OM de TMV, tanto na infecção simples como dupla foram muito baixas e não se observou efeito sinérgico na concentração de PVX.
\end{abstract}

\section{INTRODUCTION}

Tomato (Lycopersicon esculentum Mill.), an annual plant of the family Solanaceae, is an important fruit crop in most parts of the world. Generally, a number of viruses singly infecting this host are known to have potential to inflict severe economic losses. These include several strains of the Tobacco mosaic virus (TMV) genus Tobamovirus (Cassels \& Herrick, 1977; Fraser et al., 1986). In nature, many diseases of great economic importance to growers result from a mixture of different agents impinging the host at a given time. A "streak disease" often occurs in tomato when mixed infected with 
TMV and Potato virus X (PVX)genus Potexvirus (Matthews, 1991). This is characterized by severe mosaic, leaf distortion, necrotic lesions, stunting, and even premature death of plants infected at a very young age.

Related and unrelated viruses can often replicate in the same cells and may interact synergistically or antagonistically (Otsuki \& Takebe, 1976) while the concentration of one or both may significantly increase. In a mixed infection involving PVX and Potato virus $Y$ family Potyviridae genus Potyvirus (PVY), PVX was reportedly enhanced while PVY remained unchanged (Vance, 1991). The titer of the Bean pod mottle virus (BPMV) family Comoviridae genus Comovirus in soybean [Glycine max (L.) Merril], as determined by enzymelinked immunosorbent assay (ELISA), varied with leaf position and correlated well with symptom severity in plants singly and doubly infected with Soybean mosaic virus (SMV) family Potyviridae genus Potyvirus (Calvert \& Ghabrial, 1983).

Different mechanisms have been reported for enhancement of viruses under mixed infections. The increase of PVX by PVY or TMV in tobacco (Nicotiana tabacum L.) results from enhanced concentration and increased synthesis per cell and not from an increase in the number of cells infected (Goodman \& Ross, 1974a). In the mixed infection involving Cucumber mosaic virus (CMV) family Bromoviridae genus Cucumovirus and Turnip mosaic virus (TuMV) family Potyviridae genus Potyvirus, the enhancement of CMV was largely attributed to an increase in the number of CMVinfected cells (Ishimoto et al., 1990). Barker (1987) attributed enhancement of Potato leafroll virus (PLRV) genus Luteovirus by PVY in tobacco to the enhanced transport of the virus. The increase of CMV concentration in cucumber (Cucumis sativus L.) plants co-infected with Zucchini yellow mosaic virus (ZYMV) family Potyviridae genus Potyvirus (Poolpol \& Inouye, 1986). Vance (1991) reported alteration in the replication of PVX RNA leading to higher accumulation of anti-sense RNA of PVX in co-infections with PVY.

The objectives of this study were to evaluate the effect of TMV-susceptible and resistant cultivars, and severe and attenuated strains of TMV on the enhancement of PVX in mixed infected tomato, as well as elucidate mechanisms involved in disease development.

\section{MATERIALS AND METHODS}

\section{Plants and viruses}

Seedlings of Fukuju ${ }^{\circ}$ 2, a common Japanese tomato cultivar, and GCR 237 (Tm-1), genetically resistant to TMV, were raised under greenhouse conditions with a maximum temperature of $30{ }^{\circ} \mathrm{C}$ and a minimum of $18{ }^{\circ} \mathrm{C}$. Sandy loam soil, steam-sterilized at $121{ }^{\circ} \mathrm{C}$ for $30 \mathrm{~min}$, and vermiculite including NPK elements, supplemented at planting and/or transplanting, served as the growth medium. The arrangement of the pots was completely randomized.

PVX strain O and TMV strains L, (tomato strain or Tomato mosaic virus), OM (wild strain), and $\mathrm{L}_{11} \mathrm{~A}$ (attenuated strain) multiplied in N. tabacum cv. Xanthi and purified by standard procedures were used. Plants at the 5-leaf stage were inoculated with each virus alone, or simultaneously with a mixture of equal quantities of PVX and TMV, by rubbing the lower two leaves, which were lightly dusted with carborundum with a suspension of $0.2 \mathrm{mg} / \mathrm{ml}$ of virus in phosphate buffer alone $\mathrm{pH}$ 7.0. Plants that were inoculated with the buffer only served as controls.

\section{Preparation of antibodies}

Antibodies against TMV (L, $\mathrm{L}_{11} \mathrm{~A}$, and $\left.\mathrm{OM}\right)$ and PVX were raised in rabbits essentially as described in Sambrook et al. (1989). The sera, collected seven days after the last booster inoculation, had a dilution end point titer value of 1:1,024 (tube precipitin test) and were used for purifying $\operatorname{IgG}$ by the saturated ammonium sulfate solution precipitation method. The purified IgG preparations, treated with acetone extractsfree powder prepared from healthy tomato leaves, were conjugated to enzyme grade alkaline phosphatase (E.C 3.1.3.1) from calf intestine (Wako Life science reagents, Japan) essentially according to the basic procedure outlined in short protocols in molecular biology (Ausubel et al., 1995).

\section{Bacterial expression and purification of the PVX-ORF2 protein and antibody preparation}

First strand cDNA, synthesized from PVX-RNA prepared from purified PVX particles, was extended from oligo (dT) by reverse transcriptase (RT), (Amersham). The complete ORF2-cDNA was synthesized by PCR using primers with 5': GATCAGATCTAAGATGGATATTCTCATC and 3': GATC AAGCTTAGTCTATGTCC CTGCGCG in 28 cycles of $94^{\circ} \mathrm{C}$ for $20 \mathrm{~s} ; 55^{\circ} \mathrm{C}$ for $45 \mathrm{~s}$; and $68^{\circ} \mathrm{C}$ for $30 \mathrm{~s}$. The synthesized cDNA was checked before being cloned into the pQE14 vector of QIA-expression system (QIAGEN), according to the standard protocol (Sambrook et al., 1989). The insertion of the ORF2 gene into the BglII-HindIII sites downstream of the $6 \mathrm{x}$ histidine-mouse dihydrofolate reductase of pQE14 generated a plasmid recombinant that was then transformed in Escherichia coli M15. Confirmation of expression of the fusion protein in several selected colonies was done by SDSPAGE in small-scale experiments. The expression of the fusion protein was induced by addition of IPTG $(2 \mathrm{mM})$ to a culture of the recombinant bacterium in LB medium containing ampicillin and kanamycin. After $4 \mathrm{~h}$, the culture was harvested and lyzed for $1 \mathrm{~h}$ in Tris-phosphate (TP) buffer containing 8 $\mathrm{M}$ urea. The extract was centrifuged, and the supernatant passed through Ni-NTA resin column. The fusion protein, which was then eluted by gradient $\mathrm{pH}$ of TP buffer (containing $8 \mathrm{M}$ urea), was confirmed by SDS-PAGE. Antibody specific to the protein was raised in rabbits following the same procedure outlined in Sambrook et al. (1989).

\section{Sodium dodecyl sulfate-Polyacrylamide gel electrophoresis (SDS-PAGE) and Western blot analysis}

Protein fractionation and Bestern blot analysis were carried out essentially by the standard method (Sambrook et 
al., 1989). Leaf samples from the same position were collected from infected and healthy plants and macerated, with precooled mortars and pestles, in homogenizing buffer $(0.05 \mathrm{M}$ Tris- $\mathrm{HCl}$, pH 6.8 containing $0.1 \%$ PMSF or $0.1 \% 2$ Mercaptoethanol) at a ratio of $1 \mathrm{~g}$ to $10 \mathrm{ml}$ of buffer. Samples were analyzed on $12 \%$ or $15 \%$ gels and for immunoblotting analysis; proteins were electrotransferred to hybond-C extra nitrocellulose membrane (Amersham life science). Antiviral $\mathrm{IgG}$ and anti-25 $\mathrm{kDa}$ (PVX) antibody were used at $5 \mu \mathrm{g} / \mathrm{ml}$ of blocking buffer (5\% skim milk in PBS containing $0.05 \%$ Tween 20 and $0.02 \% \mathrm{NaN}_{3}$ ), and goat anti-rabbit antibodyalkaline phosphatase conjugate (Biosource International, Camarillo Ca. USA) was used as secondary antibody at 1:1,000 dilution. Visualization of virus-specific protein bands was achieved in $15 \mathrm{ml}$ of alkaline phosphatase buffer $(100 \mathrm{mM}$ Tris- $\mathrm{HCl}, \mathrm{pH}$ 9.5; $100 \mathrm{mM} \mathrm{NaCl}$; and $5 \mathrm{mM} \mathrm{MgCl}_{2}$ ) containing $100 \mu \mathrm{l}$ of $50 \mathrm{mg}$ of nitro blue tetrazolium (NBT) per ml of $70 \%$ dimethylformamide and $50 \mu$ of 5-bromo-4-chloro-3indolyl phosphate (BCIP) per $\mathrm{ml}$ of dimethylformamide.

\section{ELISA procedure}

Conventional double antibody sandwich (DAS)-ELISA was carried out essentially according to the method of Clark \& Adams (1977). Leaf samples were ground for $1 \mathrm{~min}$ in 0.02 M sodium-phosphate buffer, $\mathrm{pH} 7.2$, with precooled mortars and pestles in the ratio of $1 \mathrm{~g}$ of tissue to $10 \mathrm{ml}$ buffer. The homogenate was centrifuged for $10 \mathrm{~min}$ at 10,000 rpm and the supernatant, carefully removed, was diluted in two- fold steps in the homogenizing buffer from 1:100 to 1:12,800 for all treatments. Viral IgG-alkaline phosphatase conjugate was used at $2 \mu \mathrm{g} / \mathrm{ml}$ concentration, and color was developed with p-nitrophenyl phosphate, at $1 \mathrm{mg} / \mathrm{ml}$ concentration in $10 \%$ diethanolamine, $\mathrm{pH}$ 9.8. The concentration of each virus in the samples was estimated from a standard curve, established for each set of assay using purified virus preparations of each virus.

\section{Isolation of RNA and Northern blot hybridization}

Total RNA was isolated by the method of Logemann et al. (1987). Fresh leaf samples were frozen in liquid nitrogen and homogenized immediately to a fine powder and 2 vol. guanidine buffer [8 M guanidine hydrochloride, $20 \mathrm{mM}$ Mes (4-morpholineethansulfonic acid), $20 \mathrm{mM}$ EDTA, and $50 \mathrm{mM}$ mercaptoethanol at $\mathrm{pH}$ 7.0] were added. The homogenate was extracted with phenol/chloroform/isoamyl (25:24:1), centrifuged and the aqueous layer treated with precooled 0.7 vol. ethanol and 0.2 vol. $1 \mathrm{M}$ acetic acid to precipitate RNA. The pelleted RNA was washed twice with $3 \mathrm{M}$ sodium acetate, $\mathrm{pH} 5.2$, and finally with $70 \%$ ethanol.

An equal quantity of total RNA $(20 \mu \mathrm{g})$ of each treatment sample was fractionated on $1.2 \%$ agarose gel and transferred by capillary elution to hybond nylon membrane in 20 X SSC. An RNA probe, complementary to $350 \mathrm{nts}$ of the PVX coat protein gene, inserted into $\mathrm{T} 7$ plasmid vector and labeled with digoxigenin (DIG) (Boehringer Mannheim) according to the manufacturer's instructions, was hybridized to the total RNA. Prehybridization and hybridization as well as washing were carried out using the standard procedure (Sambrook et al., 1989). The immobilized PVX RNAs were immunodetected using anti-DIG alkaline phosphatase conjugate. Color was developed with NBT/BCIP, at twice the concentration for normal protein detection, in alkaline phosphatase buffer.

Disease development, plant growth and yield assessment

Data on symptom type and time of the first appearance, number of days to flowering after inoculation, plant height, number of leaves and stem girth were obtained. Leaf samples were collected at various periods postinoculation and kept frozen at $-40{ }^{\circ} \mathrm{C}$ until assayed for virion, viral proteins or RNAs concentration. At harvest, some shoots were cut from the base while the roots were also removed from the soil, carefully rid of attached soil particles, and then weighed. Both shoots and roots were oven-dried to constant weight at $80{ }^{\circ} \mathrm{C}$ over $24 \mathrm{~h}$. Fruits were harvested from the first round of flowering.

\section{RESULTS}

\section{Symptoms, plant growth, and yield of singly and doubly infected plants}

The manifestation of symptoms in cv. Fukuju $n^{\circ} 2$ tomato plants differed, both in time of appearance and in severity, depending on the virus strains, mode of inoculation, and season of growth (Table 1).

PVX infected plants of the cv. GCR 237 (Tm-1) manifested the usual symptoms, found in cv. Fukuju n ${ }^{\circ} 2$. Of the TMV strains tested, however, only $\mathrm{L}_{11} \mathrm{~A}$ (attenuated strain) induced a delayed, moderate mosaic symptom. The L and OM (severe strains) did not induce any symptoms. Plants that were mixed infected with $\mathrm{L}_{11} \mathrm{~A}$ and PVX eventually developed a moderate form of the characteristic symptoms observed in doubly infected TMV-susceptible plants, but the effect on growth was minimal (data not shown).

The cv. Fukuju n 2 plants doubly infected with PVX and TMV had significantly more reduced growth and yield than the singly infected ones (Table 2). Plants inoculated with TMV$\mathrm{L}_{11} \mathrm{~A}$ alone, or in combination with TMV-L, had generally better growth and yield than those infected with any of TMVL and PVX. Healthy plants had significantly better height, leaves, stem girth, as well as shoot, root and fruit yield than the infected ones, with the exception of those with TMV-L $\mathrm{L}_{11} \mathrm{~A}$ alone.

\section{Comparative concentration of viruses in singly and doubly infected plants}

PVX concentration: The inoculated primary leaves of cv. Fukuju n ${ }^{\circ} 2$ plants had generally high PVX accumulation, as measured by ELISA, while no considerable differences were found between singly and doubly inoculated ones (Table 3). In singly infected plants, inoculated leaves contained higher concentration than the systemically infected ones, while in mixed infected plants, the systemically infected upper leaf $n^{\circ}$ 5 or 7 had higher concentrations than the inoculated leaves. 
O.S. Balogun et al.

TABLE 1 - Symptoms expressed in cultivar Fukuju $\mathbf{n}^{\circ} 2$ tomato (Lycopersicon esculentum) plants singly and mixed infected with Potato virus $X(\mathrm{PVX})$ and Tomato mosaic virus (TMV) at different times of the year

\begin{tabular}{|c|c|c|c|c|}
\hline \multirow{2}{*}{ Treatment combination } & \multicolumn{2}{|c|}{ Appearance of symptoms* } & \multirow{2}{*}{$\begin{array}{l}\text { Leaf position of } \\
\text { first symptom } \\
\text { appearance** }\end{array}$} & \multirow{2}{*}{ Symptom description } \\
\hline & Summer (dpi) & Winter (dpi) & & \\
\hline TMV-L ${ }_{11} \mathrm{~A}$ alone & $21(\mathrm{x})$ & $21(\mathrm{x})$ & 7,8 & Very mild mosaic \\
\hline TMV-L alone & $5(7)$ & $6(9)$ & 5,6 & Severe mosaic \\
\hline PVX alone & $10(14)$ & $5(9)$ & 4,5 & Yellowing, rugose \\
\hline TMV-L plus TMV- $\mathrm{L}_{11} \mathrm{~A}$ & $18(28)$ & $21(28)$ & 9,10 & Mild to moderate mosaic \\
\hline PVX plus TMV-L & $5(7)$ & $4(7)$ & 4,5 & Mosaic, leaf distortion, necrotic lesions \\
\hline PVX plus TMV- $\mathrm{L}_{11} \mathrm{~A}$ & $5(8)$ & $5(7)$ & 4,5 & Mosaic, leaf distortion, necrotic lesions \\
\hline PVX before TMV-L & $9(12)$ & n.r & 5,6 & Mosaic, leaf distortion, necrotic lesions \\
\hline TMV-L before PVX & $6(14)$ & n.r & 5,6 & Mosaic, leaf distortion, necrotic lesions \\
\hline Healthy control & n.s & n.s & n.s & No symptoms \\
\hline
\end{tabular}

TABLE 2 - Data of some growth and yield parameters measured in healthy and diseased tomato (Lycopersicon esculentum) plants singly and mixed infected with Potato virus $X(\mathrm{PVX})$ and Tomato mosaic virus (TMV)

\begin{tabular}{|c|c|c|c|c|c|c|c|c|c|c|c|}
\hline \multirow{2}{*}{$\begin{array}{l}\text { Treatment } \\
\text { Combination }\end{array}$} & \multirow{2}{*}{$\begin{array}{c}\text { Height } \\
\text { at } \\
\text { harvest } \\
(\mathrm{cm})^{* *}\end{array}$} & \multirow{2}{*}{$\begin{array}{c}\text { Number } \\
\text { of leaves } \\
\text { at } \\
\text { harvest* }\end{array}$} & \multirow{2}{*}{$\begin{array}{l}\text { Stem } \\
\text { girth } \\
(\mathrm{mm})^{* *}\end{array}$} & \multicolumn{2}{|c|}{ Shoot weight (g) } & \multicolumn{2}{|c|}{ Root weight (g) } & \multirow{2}{*}{$\begin{array}{l}\text { Days to } \\
\text { flowering } \\
\text { (dpi) }\end{array}$} & \multicolumn{3}{|c|}{$\begin{array}{l}\text { Yield of edible fruits } \\
\text { at 1st harvest*** }\end{array}$} \\
\hline & & & & Fresh & Dry & Fresh & Dry & & $\begin{array}{c}\text { Mean } \\
\text { no. per } \\
\text { plant }\end{array}$ & $\begin{array}{l}\text { Mean wt. } \\
\text { per plant } \\
\text { (g) }\end{array}$ & $\begin{array}{l}\text { Mean wt. } \\
\text { of a fruit } \\
\text { (g) }\end{array}$ \\
\hline TMV-L $\mathrm{L}_{11} \mathrm{~A}$ alone & $85.3 \mathrm{~b}$ & $23 \mathrm{~b}$ & $10.6 \mathrm{~b}$ & $74.8 \mathrm{~b}$ & $11.89 \mathrm{~b}$ & $10.43 \mathrm{~b}$ & $1.74 \mathrm{~b}$ & $33.0 \mathrm{~cd}$ & $2.3 \mathrm{a}$ & $334.8 \mathrm{ab}$ & $148.5 \mathrm{ab}$ \\
\hline TMV-L alone & $70.3 \mathrm{c}$ & $16.3 \mathrm{~cd}$ & $9.0 \mathrm{~d}$ & $62.3 \mathrm{~d}$ & $9.07 \mathrm{~d}$ & $9.71 \mathrm{~b}$ & $1.59 \mathrm{~b}$ & $35.5 \mathrm{c}$ & $1.8 \mathrm{a}$ & $241.3 \mathrm{~b}$ & $138.5 \mathrm{~b}$ \\
\hline PVX alone & $64.7 \mathrm{~cd}$ & $17.8 \mathrm{c}$ & $9.4 \mathrm{~cd}$ & $63.1 \mathrm{~d}$ & $8.94 \mathrm{~d}$ & $7.51 \mathrm{c}$ & $1.19 \mathrm{c}$ & $30.5 \mathrm{~d}$ & $1.8 \mathrm{a}$ & $247.5 \mathrm{~b}$ & $142.9 \mathrm{ab}$ \\
\hline TMV-L plus TMVL ${ }_{11} \mathrm{~A}$ & $78.2 \mathrm{~b}$ & $21.8 \mathrm{~b}$ & $10.1 \mathrm{bc}$ & $69.2 \mathrm{c}$ & $10.43 \mathrm{c}$ & $9.94 \mathrm{~b}$ & $1.60 \mathrm{~b}$ & $32.3 \mathrm{~d}$ & $1.8 \mathrm{a}$ & $244.0 \mathrm{~b}$ & $141.4 \mathrm{~b}$ \\
\hline PVX plus TMV-L & $51.9 \mathrm{e}$ & $13.8 \mathrm{e}$ & $7.0 \mathrm{e}$ & $46.6 \mathrm{f}$ & $6.21 \mathrm{f}$ & $5.18 \mathrm{~d}$ & $0.74 \mathrm{e}$ & $48.5 \mathrm{a}$ & $0.3 \mathrm{~b}$ & $17.8 \mathrm{c}$ & $71.0 \mathrm{c}$ \\
\hline PVX before TMV-L & $57.7 \mathrm{de}$ & $16 \mathrm{~cd}$ & $7.6 \mathrm{e}$ & 49.8 ef & $6.86 \mathrm{f}$ & $5.51 \mathrm{~d}$ & $0.81 \mathrm{e}$ & $44.8 \mathrm{~b}$ & $0.5 \mathrm{~b}$ & $42.5 \mathrm{c}$ & $85.0 \mathrm{c}$ \\
\hline TMV-L before PVX & $62.8 \mathrm{~d}$ & $15.5 \mathrm{de}$ & $7.7 \mathrm{e}$ & $53.0 \mathrm{e}$ & $7.71 \mathrm{e}$ & $6.78 \mathrm{c}$ & $1.04 \mathrm{~cd}$ & $45.5 \mathrm{~b}$ & $0.3 \mathrm{~b}$ & $20.5 \mathrm{c}$ & $82.0 \mathrm{c}$ \\
\hline PVX plus TMV $\mathrm{L}_{11} \mathrm{~A}$ & $52.2 \mathrm{e}$ & $14.5 \mathrm{de}$ & $7.3 \mathrm{e}$ & $48.3 \mathrm{ef}$ & $6.46 \mathrm{f}$ & $6.83 \mathrm{c}$ & $1.02 \mathrm{~d}$ & $47.0 \mathrm{ab}$ & $0.5 \mathrm{~b}$ & $41.3 \mathrm{c}$ & $82.5 \mathrm{c}$ \\
\hline Healthy control & $98.6 \mathrm{a}$ & $25.5 \mathrm{a}$ & $12.5 \mathrm{a}$ & $90.9 \mathrm{a}$ & $16.08 \mathrm{a}$ & $13.13 \mathrm{a}$ & $2.42 \mathrm{a}$ & $31.8 \mathrm{~d}$ & $2.8 \mathrm{a}$ & $442.5 \mathrm{a}$ & $161.4 \mathrm{a}$ \\
\hline
\end{tabular}

Means followed by the same letter(s) in the columns are not significantly different according to Tukey-Kramer's HSD test (P= 0.05$)$.

* Values are means of four plants at seven weeks after initial inoculations.

"Edible fruit (ripe tomato of any size) derived from the first round of flowering

TABLE 3 - Comparison of virus concentration at different leaf positions of cultivar Fukuju no 2 tomato (Lycopersicon esculentum) singly or doubly infected with Potato virus $X$ (PVX) and Tomato mosaic virus (TMV), as determined by ELISA at seven and 12 days postinoculation

\begin{tabular}{|c|c|c|c|c|c|c|c|c|c|c|}
\hline \multirow{3}{*}{ Virus } & \multirow{3}{*}{ Virus treatment } & \multicolumn{9}{|c|}{ Concentration of PVX (mg/g fresh leaf weight) at various leaf positions } \\
\hline & & \multirow{2}{*}{\multicolumn{2}{|c|}{$\begin{array}{c}\text { Inoculated leaf } \\
\text { Leaf } 1,7 \text { dpi } \\
\end{array}$}} & \multicolumn{7}{|c|}{ Systemically infected leaves } \\
\hline & & & & \multicolumn{3}{|c|}{ Leaf 3, 7 dpi } & \multicolumn{2}{|c|}{ Leaf 5, 7 dpi } & \multicolumn{2}{|c|}{ Leaf 7,12 dpi } \\
\hline \multirow[t]{3}{*}{ PVX } & PVX alone & $1.32 \pm$ & 0.04 & $0.08 \pm$ & 0.01 & & $0.30 \pm$ & 0.02 & $0.41 \pm$ & 0.07 \\
\hline & PVX + TMV-L & $1.40 \pm$ & $0.10(1.06)^{* *}$ & $0.09 \pm$ & 0.01 & $(1.15)$ & $1.91 \pm$ & $0.07(6.28)$ & $1.50 \pm$ & $0.11(3.66)$ \\
\hline & $\mathrm{PVX}+\mathrm{TMV}-\mathrm{L}_{11} \mathrm{~A}$ & $1.27 \pm$ & $0.03(0.96)$ & $0.09 \pm$ & 0.01 & (1.14) & $1.45 \pm$ & $0.10(4.83)$ & $1.15 \pm$ & $0.06(2.80)$ \\
\hline \multirow[t]{4}{*}{ TMV } & TMV-L alone & $1.92 \pm$ & 0.14 & $0.25 \pm$ & 0.01 & & $3.12 \pm$ & 0.16 & $2.15 \pm$ & 0.07 \\
\hline & TMV-L ${ }_{11}$ A alone & $1.14 \pm$ & 0.16 & $0.18 \pm$ & 0.01 & & $1.62 \pm$ & 0.12 & $1.27 \pm$ & 0.09 \\
\hline & PVX + TMV-L & $1.75 \pm$ & $0.10(0.91)$ & $0.13 \pm$ & 0.02 & $(0.52)$ & $2.42 \pm$ & $0.14(0.77)$ & $1.88 \pm$ & $0.18(0.87)$ \\
\hline & PVX + TMV- $\mathrm{L}_{11} \mathrm{~A}$ & $1.09 \pm$ & $0.13(0.95)$ & $0.13 \pm$ & 0.01 & $(0.71)$ & $1.54 \pm$ & $0.08(0.95)$ & $1.20 \pm$ & $0.08(0.94)$ \\
\hline
\end{tabular}

Values are means \pm standard deviation obtained from four plants with each extract tested in duplicate wells.

Values in parentheses represent the ratios of the concentration of the respective viruses in doubly : singly infected plants. 
The concentration in mixed infected upper leaves was also several-fold higher than that in comparable leaf positions of singly infected plants. Enhancement was consistently higher in plants with TMV-L + PVX, than in those with PVX and $\mathrm{L}_{11} \mathrm{~A}$.

In the inoculated leaves of GCR 237 (Tm-1) plants, equally early substantial accumulation of PVX was found both in the singly inoculated and in doubly inoculated plants. PVX concentration in the systemically infected upper leaf 5 , at 7 dpi (data not shown) and at 12 dpi (Table 4) remained at the same levels for both singly infected and doubly infected plants. In the uppermost leaf 8 , at $18 \mathrm{dpi}$, PVX concentration was 3-fold higher than in plants with $\mathrm{PVX}+\mathrm{L}_{11} \mathrm{~A}$ treatment, relative to singly inoculated plants, and those with TMV-L + PVX or PVX + TMV-OM treatments, all of which remained at the same levels.

TMV concentration: The mean concentrations of both TMV strains, in doubly infected cv. Fukuju n ${ }^{\circ} 2$ plants were relatively lower than those in singly infected plants but TMV-L was found to be generally higher than that of the $\mathrm{L}_{11} \mathrm{~A}$, single or mixed infection not withstanding (Table 3 ). The ratio of concentration in doubly infected plants to that in singly infected plants for the two strains was lower, leaf for leaf, for TMV-L than for TMV-L ${ }_{11} \mathrm{~A}$, but was more pronounced in the systemically infected upper leaves.

In cv. GCR 237 (Tm-1), of all the TMV strains tested, only TMV-L $\mathrm{L}_{11} \mathrm{~A}$ accumulated considerable levels in both singly and doubly inoculated plants. Although at undetectable level by ELISA, at $7 \mathrm{dpi}$, both in the inoculated and upper leaf 5, it reached some substantial level in leaf $\mathrm{n}^{\circ}$ 8 sampled and analyzed 18 days postinoculation (Table 4).

\section{Virus-specific proteins accumulated in singly and doubly infected leaves}

In the inoculated primary leaves of cv. Fukuju $\mathrm{n}^{\mathrm{o}} 2$ plants, both TMV and PVX coat proteins assayed 3, 5 or 7 dpi, by Western blot analysis, showed increased concentrations which remained respectively at about the same levels in both singly and doubly infected plants. TMV$\mathrm{L}$ was detected in the upper leaf $\mathrm{n}^{\circ} 5$ of plants under single inoculation 3 dpi. It increased to substantial levels at $5 \mathrm{dpi}$ and then stabilized at $7 \mathrm{dpi}$. In contrast, however, its systemic movement and accumulation under mixed infection, to and in the upper leaves, fell short of the speed and the quantity observed in singly inoculated plants (Figure 1A, C, D). PVX's CP concentration was higher and continued to increase in the doubly infected upper leaves compared to singly infected ones as at 12 dpi (Figure 2A).

The PVX ORF2-encoded $25 \mathrm{kDa}$ triple gene block (TGB) protein was first faintly detected at $3 \mathrm{dpi}$ in the inoculated leaves of both singly and doubly infected plants. The level at 5 dpi is shown in Figure 1B. The quantity in systemically infected leaves of doubly infected plants increased more rapidly with time than that in singly infected ones. Figure 2B shows the relative levels in leaves 5 and 7 at 12 dpi.

In cv. GCR 237 (Tm-1), relatively early high accumulation of PVX CP, was observed in both single and mixed infection. On the other hand, as at $7 \mathrm{dpi}$, the TMV strains were neither detected in the inoculated leaves (i.e. nos. 1 and 2) nor in leaf 5 by Western blot analysis. Samples at 12 dpi had substantial accumulation of $\mathrm{L}_{11} \mathrm{~A}$ in leaf $\mathrm{n}^{\circ} 5$ in both singly and doubly infected plants (Figure 3). The OM strain's CP was detected only by $18 \mathrm{dpi}$, albeit in very minute quantity, but that of L was not. Significantly higher concentrations of PVX CP were observed in plants with PVX plus $\mathrm{L}_{11} \mathrm{~A}$.

PVX RNA accumulated in singly and mixed infected plants A time course analysis of the acute stage leaf $n^{\circ} 5$ from cv. Fukuju n 2 plants, from day five through 12 , by

TABLE 4 - Comparison of virus concentration in different leaf positions of cultivar GCR 237 (Tm-I) tomato (Lycopersicon esculentum) plants, at various times following single or mixed inoculation with Potato virus X (PVX) and Tomato mosaic virus (TMV), as determined by ELISA

\begin{tabular}{|c|c|c|c|c|c|c|c|c|}
\hline \multirow{3}{*}{$\begin{array}{l}\text { Virus } \\
\text { PVX }\end{array}$} & \multirow{3}{*}{$\begin{array}{l}\text { Virus treatment } \\
\text { PVX alone }\end{array}$} & \multicolumn{7}{|c|}{ Leaf position, and day postinoculation (dpi) of sampling for assay } \\
\hline & & Leaf 1, 7 dpi & \multicolumn{3}{|c|}{ Leaf 5, 12 dpi } & \multicolumn{3}{|c|}{ Leaf 8, $18 \mathrm{dpi}$} \\
\hline & & $0.57 \pm 0.05^{*}$ & $0.43 \pm$ & 0.04 & & $0.47 \pm$ & 0.06 & \\
\hline & PVX + TMV-L & $0.51 \pm 0.04(0.89)^{* *}$ & $0.40 \pm$ & 0.05 & $(0.93)$ & $0.48 \pm$ & 0.01 & $(1.02)$ \\
\hline & $\mathrm{PVX}+\mathrm{TMV}^{-\mathrm{L}_{11} \mathrm{~A}}$ & $0.58 \pm 0.06(1.02)$ & $0.51 \pm$ & 0.02 & (1.19) & $1.43 \pm$ & 0.07 & $(3.04)$ \\
\hline & $\mathrm{PVX}+\mathrm{TMV}-\mathrm{OM}$ & $0.54 \pm 0.03(0.95)$ & $0.39 \pm$ & 0.02 & $(0.91)$ & $0.46 \pm$ & 0.03 & $(1.11)$ \\
\hline \multirow[t]{6}{*}{ TMV } & TMV-L alone & $\mathrm{ND}^{* * * *}$ & $0.04 \pm$ & 0.00 & & $0.08 \pm$ & 0.02 & \\
\hline & TMV-L + PVX & ND & $0.04 \pm$ & 0.00 & $(0.98)$ & $0.08 \pm$ & 0.01 & $(0.97)$ \\
\hline & TMV-L ${ }_{11} \mathrm{~A}$ alone & ND & $0.25 \pm$ & 0.01 & & $0.78 \pm$ & 0.03 & \\
\hline & TMV-L ${ }_{11} \mathrm{~A}+\mathrm{PVX}$ & ND & $0.24 \pm$ & 0.02 & $(0.96)$ & $0.81 \pm$ & 0.02 & $(1.04)$ \\
\hline & TMV-OM alone & ND & $0.06 \pm$ & 0.01 & & $0.16 \pm$ & 0.01 & \\
\hline & TMV-OM + PVX & ND & $0.06 \pm$ & 0.01 & $(0.98)$ & $0.15 \pm$ & 0.01 & $(0.98)$ \\
\hline
\end{tabular}

\footnotetext{
*Values are means \pm standard deviation from three plants independently assayed

**Values in parentheses are ratios of the concentration of the respective viruses in doubly to that in singly infected plants
}

***ND =virus not detectable 
O.S. Balogun et al.

A
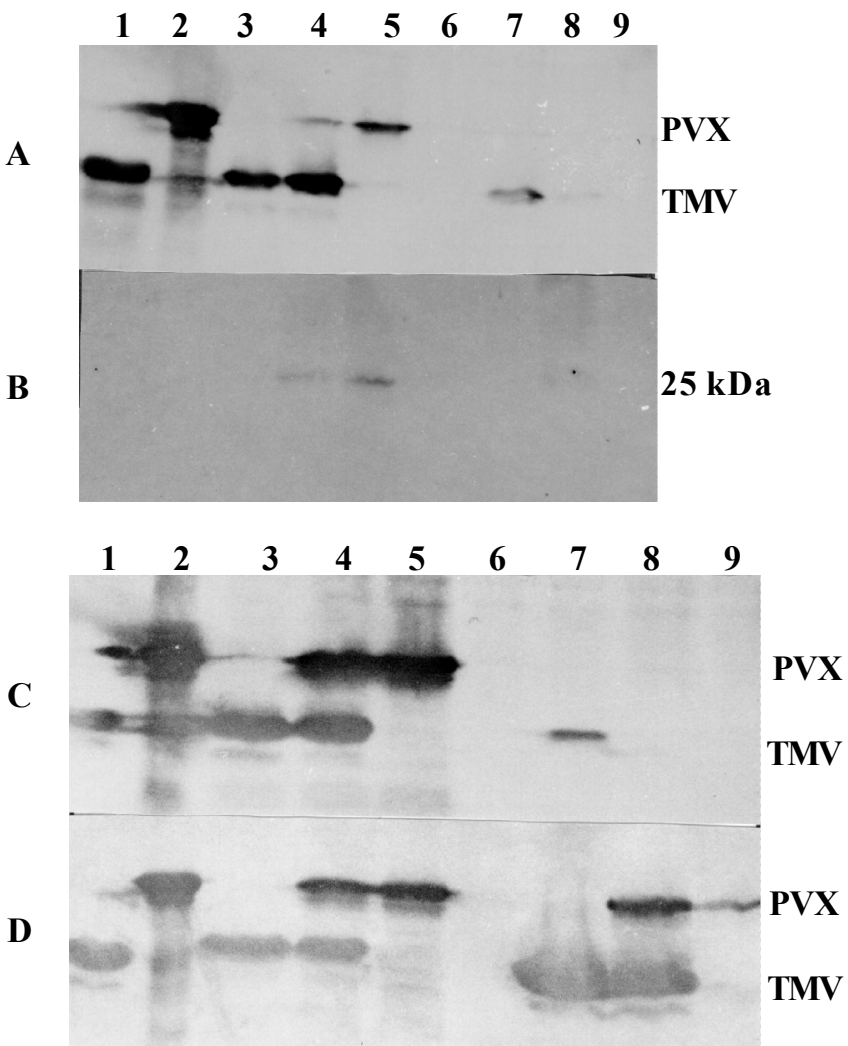

FIG. 1 - Western blot analysis of some accumulated viral proteins in inoculated and systematically infected leaves of tomato (Lycopersicon esculentum) cv Fukuju $n^{0} 2$ plants singly or doubly inoculated with Potato virus $X(\mathrm{PVX})$ and Tomato mosaic virus (TMV-L).

Lanes: 1- purified TMV; 2- purified PVX; 3TMV alone; 4- PVX + TMV-L; 5- PVX alone, 6- buffer only (control); 7- TMV-L alone; 8PVX-TMV-L and 9-PVX alone; Lanes: 3 to 6inoculated leaf, 7 to 9- systemically infected leaf. A) leaf 5 at $3 \mathrm{dpi}, \mathrm{B})$ leaf 5 at $5 \mathrm{dpi}, \mathrm{C}$ ) leaf 3 at 5 dpi, and D) leaf 5 at $5 \mathrm{dpi}$. A, C and D are coat proteins $(\mathrm{CP})$ of $\mathrm{PVX}$ and $\mathrm{TMV}-\mathrm{L}$, and $\mathrm{B}=25 \mathrm{kDa}$ protein of PVX.

Northern blot hybridization of total RNA, revealed the gradual accumulation of both the genomic and subgenomic RNAs in all infected plants. The doubly infected leaf, however, had considerably bolder hybridization signal in contrast to singly infected ones, especially at 5 and $12 \mathrm{dpi}$. The differences became less apparent, with age of infections, as observed in the chronic stage upper leaf $\mathrm{n}^{\circ} 12$ sampled at 28 dpi (data not shown).

\section{DISCUSSION}

The enhancement of PVX viral components during disease development, as influenced by differences in TMV strains and tomato host cultivar, exert substantial influence

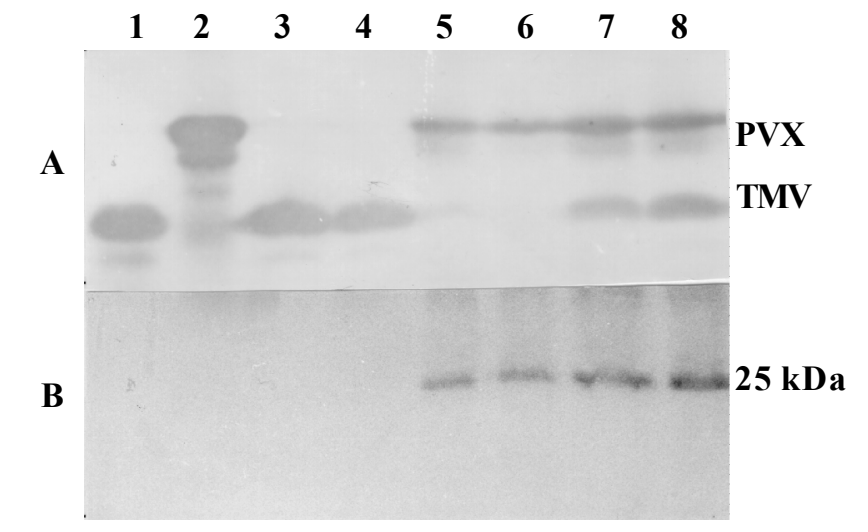

FIG. 2 - Western blot analysis of some accumulated viral proteins in leaf 5 and 7 of singly and doubly infected leaves of tomato (Lycopersicon esculentum) cv Fukuju $n^{\circ} 2$ plants 12 days following inoculation with Potato virus $X$ (PVX) and Tomato mosaic virus (TMV-L).

Lanes: 1- purified TMV; 2- purified PVX virion, 3- TMV alone in leaf 5; 4- TMV alone in leaf 7; 5- PVX alone in leaf 5; 6- PVX alone in leaf 7; 7PVX+TMV-L in leaf 5; 8- PVX-TMV-L in leaf 7; 9-PVX alone; A) coat proteins of both PVX and TMV-L; B) PVX $25 \mathrm{kDa}$ protein in the same samples. The positions of PVX and TMV bands are indicated.

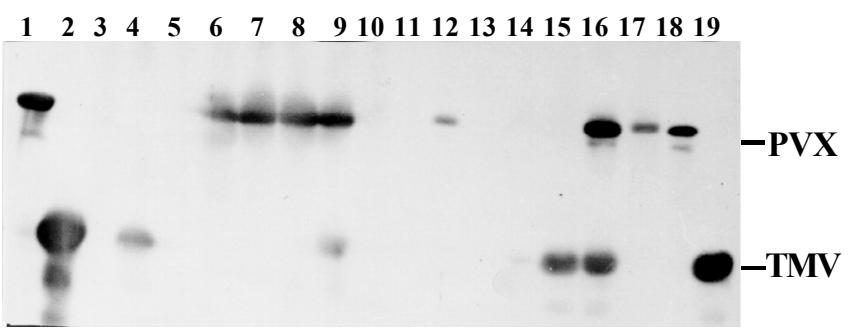

FIG. 3 - Western blot analysis of the coat proteins accumulated in systemically infected leave 5 at $12 \mathrm{dpi}$, and leaf 8 at $18 \mathrm{dpi}$ in tomato (Lycopersicon esculentum) cv GCR 237 (Tm-1) plants after inoculation with Potato virus $X$ (PVX) and Tomato mosaic virus (TMV-L). Lanes: 1, 2 and 19- purified PVX, TMV-L and TMV-L ${ }_{11}^{A}$, respectively; lanes: 3 to 5- TMVL, TMV-L $\mathrm{L}_{11} A$ and TMV-OM alone, respectively; Lanes: 6 to $10-\mathrm{PVX}$ alone, $\mathrm{PVX}+$ TMV-L, PVX + OM, PVX $+\mathrm{L}_{11} A$ and control, respectively; Lanes: 3 to 10 are samples from leaf 5 at 12 dpi; Lanes: 11 to 18 are samples of leaf 8 collected at 18 dpe; 11- control; 12- PVX + TMV-L ${ }_{11}$ A alone; 16- PVX + $\mathrm{L}_{11} \mathrm{~A}$; 17- PVX $+\mathrm{OM}$, and 18- PVX alone. The positions of PVX and TMV are shown to the right of the figure. 
on the consequent tomato responses. The observed differences, both in the extent of individual replication and PVX-enhancing ability between the two strains of TMV may have stemmed from their basic genomic differences. Indeed, comparison of the complete nucleotide sequence of $\mathrm{L}_{11} \mathrm{~A}$ with that of the ancestral wild strain (L) Nishiguchi et al. (1985) showed ten nucleotide substitutions in $\mathrm{L}_{11} \mathrm{~A}$, all located in the $130 \mathrm{~K}$ and $180 \mathrm{~K}$ protein genes. Amino acid changes were, however, associated with only three of the nucleotide substitutions. The $130 \mathrm{~K}$ and $180 \mathrm{~K}$ proteins are known to take part in virus RNA replication (Ishikawa et al., 1986).

In relation to earlier reports on mixed infection, our results are in line with those of some earlier workers (Calvert \& Ghabrial, 1983; Vance, 1991) who also reported lack of significant enhancement of any of the interacting viruses in the inoculated leaves. Although they reported no changes in the concentration of the enhancing virus, in the acute stage upper leaves of tomato that would support enhancement of PVX, we observed that the mean concentration of TMV-L was about $25 \%$ lower than the average in comparable leaves of singly infected plants (Table 4). The effects of the mild strain, however, remained at about the same level in both cases, which further supports our idea that TMV strains do influence the enhancement of PVX, and hence the general mixed infection process. Poolpol \& Inouye (1986) reported a reduction in the concentration of ZYMV in doubly infected plants while that of CMV increased in cucumber plants.

In cv. GCR 237 with the Tm-1 gene that confers homozygous resistance to some TMV strains, the L and OM strains accumulated to very low levels in systemically infected upper leaves in both singly and doubly inoculated plants. Consequently, despite concentration of PVX remaining high, there was no significant enhancement in the doubly over singly infected plants. The absence of the characteristic symptoms of mixed infection was also notable. The $\mathrm{L}_{11} \mathrm{~A}$ strain that substantially accumulated early enough to overcome the resistance led to enhanced concentration of PVX in mixed infected plants. It is apparent from these results that the mere presence of TMV strains in the mixed infection is not a sufficient requirement for the enhancement of PVX concentration. The enhancing TMV strain must not only be able to replicate in the host cultivar, it also must be capable of doing so to a certain substantial level, at a time that coincides with active PVX replication. Goodman \& Ross (1974b) have also observed that enhancement of the synthesis of PVX by PVY in doubly infected tobacco depends on the timing of invasion by the viruses.

Movement enhancing by TMV is one possible mechanism employed in the overall concentrationenhancement of PVX in tomato. Significant differences were observed between inoculated and systemically infected leaves within the respective treatments. Western blot analysis also showed that the systemic movements of TMV-L as well as its concentration are slowed significantly under simultaneous mixed infection with PVX (Figure 1A, C, D). These results supports this possibility.

The relatively enhanced level of the $25 \mathrm{kDa}$ protein in the systemically infected leaves may also have some implication for overall PVX concentration enhancement in mixed infected plants. The ability of PVX to increase the plasmodesmal size exclusion limit (SEL) of infected tobacco cell has been attributed to the $25 \mathrm{kDa}$ TGB protein (Angell et al., 1996), although other viral proteins may also be involved. The enhanced level may also have led to the reductions observed in TMV concentration, through a possible slowing-down-strategy, in doubly infected plants. Ares et al. (1998) reported a substantial resistance to TMV in transgenic tobacco plant expressing the ORF2 protein (P24) of PVX.

The considerably high level of PVX genomic RNA, in the TMV-susceptible tomato cultivar (Figure 4), especially as observed during the acute stage of disease, could be responsible for sustained high synthesis of virion and, hence, the higher accumulation of virion. A change in the regulation of PVX RNA replication in doubly infected cells was also credited with the synergistic increase in PVX accumulation in a mixed infection with PVY (Vance, 1991), and this was invariably associated with increased pathogenicity in tobacco plants.

This study demonstrated that a mixed infection of tomato with TMV and PVX, which normally results in more severe disease symptoms involves alterations in the accumulation of PVX components.

This is influenced to a considerable extent by virus strains and the cultivars of tomato involved. The best longterm means of protection, as observed by Crute \& Pink

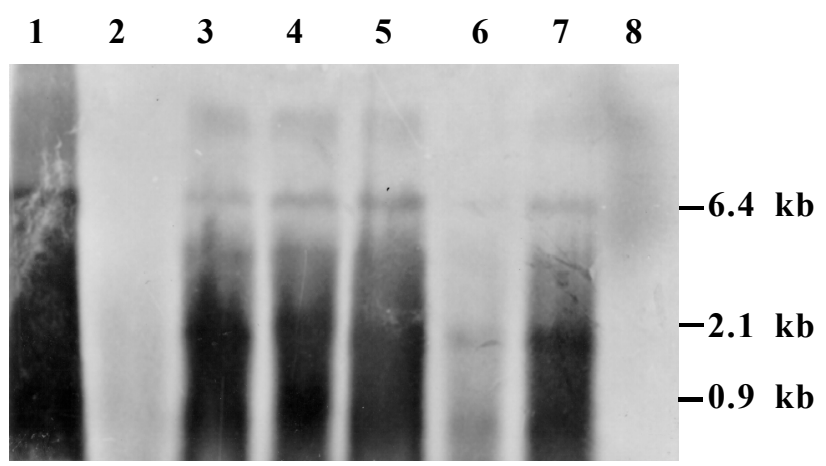

FIG. 4 - Northern blot hybridization of accumulated Potato virus $X$ (PVX) RNAs in leaf 5 of singly and doubly infected tomato (Lycopersicon esculentum) cv Fukuju no 2 plants at five, nine and 12 days after inoculation with PVX and Tomato mosaic virus (TMV-L).

Lanes: 1- PVX virion RNA; 2- PVX at 5 dpi; 3PVX + TMV-L at 5 dpi; 4- PVX at 9 dpi; 5- PVX + TMV-L at 9 dpi; 6- PVX at 12 dpi; 7- PVX + TMV-L at 12 dpi; 8- TMV-L at 12 dpi. The size of the genomic and subgenomic RNAs is indicated in kilobase to the right of the figure. 
(1996), has proven to be cultivar-specific resistance controlled by a resistance gene that is specific to a particular virus, therefore, is the best hope for curtailing the disease studied.

\section{ACKNOWLEDGEMENT}

This work was supported by a grant-in-aid from the Japanese Ministry of Education, Science and Culture (Monbusho), for which we are grateful.

\section{LITERATURE CITED}

ANGELL, S. M., DAVIES, C. \& BAULCOMBE, D.C. Cell-tocell movement of potato virus $\mathrm{X}$ is associated with a change in the size-exclusion limit of plasmodesmata in trichome cells of Nicotiana clevelandii. Virology 216:197-201. 1996.

ARES, X., CALAMANTES, G., CABRAL, S., LODGE, J., HEMENWAY, P., BEACHY, R. N. \& MENTABERRY, A. Transgenic plants expressing potato virus X ORF2 protein (p24) are resistant to tobacco mosaic virus and $\mathrm{Ob}$ tobamoviruses. Journal of General Virology 72:731-738. 1998.

AUSUBEL, F., BRENT, R., KINGSTON, E.R., MOORE, D.D., SEIDMAN, J.G., SMITH, J.A. \& STRUHL, K. Short Protocols in Molecular Biology $3^{\text {rd }}$ ed. John Wiley \& Sons Inc. 1995.

BARKER, H. Invasion of non-phloem tissue in Nicotiana clevelendii by potato leaf roll luteovirus is enhanced in plants also infected with potato virus Y. Journal of General Virology 68:1223-1227. 1987.

CALVERT, L.A. \& GHABRIAL, S.A. Enhancement by soybean mosaic virus of bean pod mottle virus titer in doubly infected soybean. Phytopathology 73:992-997. 1983.

CASSELS, A.C. \& HERRICK, C.C. Cross protection between mild and severe strains of tomato mosaic virus in doubly inoculated tomato plants. Virology 78:253 -260. 1977.

CLARK, M.F. \& ADAMS, A.N. Characteristics of the microplate method of enzyme linked immunosorbent assay for the detection of plant viruses. Journal of General Virology 34:475483. 1977.

CRUTE, I.R. \& PINK, D.A.C. Genetics and utilization of pathogen resistance in plants. Plant Cell 8:1747-1755. 1996.
FRASER, R.S.S., GERWITZ, A. \& MORRIS, G.E.L. Multiple regression analysis of the relationships between tobacco mosaic virus multiplication, severity of mosaic symptoms, and the growth of tobacco and tomato. Physiology Molecular Plant Pathology 29:239-249. 1986.

GOODMAN, R.M. \& ROSS, A.F. Enhancement of potato virus X in doubly infected tobacco occurs in doubly infected cells. Virology 58:16-24. 1974a.

GOODMAN, R.M. \& ROSS, A.F. Enhancement by potato virus Y of potato virus $\mathrm{X}$ synthesis in doubly infected tobacco depends on the timing of invasion by the viruses. Virology 58:263271. 1974b.

ISHIKAWA, M., MESHI, T., MOTOYOSHI, F., TAKAMATSU, N. \& OKADA, Y. In vitro mutagenesis of the putative replicase genes of tobacco mosaic virus. Nucleic Acids Research. 14:8291-8305. 1986.

ISHIMOTO, M., SANO, Y. \& KOJIMA, M. Increase in cucumber mosaic virus concentration in Japanese radish plants coinfected with turnip mosaic virus (11) Electron microscope and immunological observations. Annual Phytopathological Society Japan 56: 63-72. 1990.

LOGEMANN, J., SCHELL, J. \& WILLMITZER, L. Improved method for the isolation of RNA from plant tissues. Anals Biochemistry 163: 16-20. 1987.

MATTEWS, R E.F. Plant Virology $3^{\text {rd }}$ ed. Academic Press, San Diego. 1991.

NISHIGUCHI, M., KIKUCHI, S., KIHO, Y., OHNO, T., MESHI, T. \& OKADA, Y. Molecular basis of plant viral virulence; the complete nucleotide sequence of an attenuated strain of tobacco mosaic virus. Nucleic Acids Research 13: 5585-5590. 1985.

OTSUKI, Y. \& TAKEBE, I. Double infection of isolated tobacco mesophyll protoplasts by unrelated viruses. Journal of General Virology 30:309-316. 1976.

POOLPOL, P. \& INOUYE, T. Enhancement of cucumber mosaic virus multiplication by zucchini yellow mosaic virus in doubly infected cucumber plants. Annual Phytopathological Society Japan 52:22-30. 1986.

SAMBROOK.J., FRISTCH, E.F. \& MANIATIS, T. Molecular Cloning: A laboratory manual. $2^{\text {nd }}$ ed. Cold Spring Harbor Laboratory, Cold Spring Harbor, NY. 1989.

VANCE, V.B. Replication of potato virus X RNA is altered in coinfections with potato virus Y. Virology 182:486-494. 1991. 